\title{
Mass Spectral Behavior of the Hydrolysis Products of Sesqui- and Oxy-Mustard Type Chemical Warfare Agents in Atmospheric Pressure Chemical Ionization
}

\author{
Sharon W. Lemire, Doris H. Ash, Rudolph C. Johnson, and John R. Barr \\ Division of Laboratory Sciences, National Center for Environmental Health, Centers for Disease Control and \\ Prevention, Atlanta, Georgia, USA
}

\begin{abstract}
Bis(2-hydroxyethylthio)alkanes and bis(2-hydroxyethylthioalkyl)ethers are important biological and environmental degradation products of sulfur mustard analogs known as sesqui- and oxy-mustards. We used atmospheric pressure chemical ionization mass spectrometry (APCI MS) to acquire characteristic spectra of these compounds in positive and negative ionization modes. Positive APCI mass spectra exhibited $[\mathrm{M}+\mathrm{H}]^{+}$; negative APCI MS generated $[\mathrm{M}+$ $\left.\mathrm{O}_{2}\right]^{-},[\mathrm{M}-\mathrm{H}]^{-}$, and $[\mathrm{M}-3 \mathrm{H}]^{-}$; and both positive and negative APCI mass spectra contained fragment ions due to in-source collision-induced dissociation. Product ion scans confirmed the origin of fragment ions observed in single-stage MS. Although the spectra of these compounds were very similar, positive and negative APCI mass spectra of the oxy-mustard hydrolysis product, bis(2-hydroxyethylthiomethyl)ether, differed from the spectra of the other compounds in a manner that suggested a rearrangement to the sesqui-mustard hydrolysis product, bis(2-hydroxyethylthio)methane. We evaluated the $\left[\mathrm{M}+\mathrm{O}_{2}\right]^{-}$adduct ion for quantification via liquid chromatography-MS/MS in the multiple-reaction monitoring (MRM) mode by constructing calibration curves from three precursor/product ion transitions for all the analytes. Analytical figures of merit generated from the calibration curves indicated the stability and suitability of these transitions for quantification at concentrations in the low $\mathrm{ng} / \mathrm{mL}$ range. Thus, we are the first to propose a quantitative method predicated on the measurement of product ions generated from the superoxide adduct anion of the sesqui-and oxy-mustard hydrolysis products. (J Am Soc Mass Spectrom 2007, 18, 1364-1374) (C) 2007 American Society for Mass Spectrometry
\end{abstract}

S ulfur mustards are potent vesicants with a history of use in armed conflicts as chemical warfare agents (CWA) [1,2]. Besides the commonly known bis(2-chloroethyl)sulfide (HD), five sesqui- and two oxy-mustard analogs are included on the Chemical Weapons Convention (CWC) Schedule of Chemicals [3]. These mustard analogs were first synthesized in 1921 [4] and may be found as impurities in munitionsgrade mustard formulations along with other longer chain mustards and sulfur contaminants [5, 6]. More specifically, the sesqui-mustard 1,2-bis(2-chloroethylthio)ethane (Agent $\mathrm{Q}$ ) and the oxy-mustard bis(2-chloroethylthioethyl)ether (Agent $\mathrm{T}$ ) are major components in the weapons-grade munitions designated $\mathrm{HQ}$ and $\mathrm{HT}$, respectively [7]. As vesicants, these compounds are two to five times more potent than HD [8] with estimated human $\mathrm{LC}_{50}$-time relationships for inhalation exposure of $300 \mathrm{mg}-\mathrm{min} / \mathrm{m}^{3}$ (Agent $\mathrm{Q}$ ) and $400 \mathrm{mg}$ $\mathrm{min} / \mathrm{m}^{3}$ (Agent T) [9] compared with $1500 \mathrm{mg}-\mathrm{min} / \mathrm{m}^{3}$

Address reprint requests to Dr. Sharon W. Lemire, Division of Laboratory Sciences, National Center for Environmental Health, Centers for Disease Control and Prevention, MS-F44, 4770 Buford Highway, NE, Atlanta, GA 30341-3724, USA. E-mail: SLemire@CDC.GOV
(HD) [10]. Thus, although the biological effects of exposure to HQ and HT are similar to those observed for $\mathrm{HD}$, the presence of Agent $\mathrm{Q}$ or $\mathrm{T}$ increases the activity of these mixtures [10]. Sesqui- and oxymustards are a public health concern because of the risk of exposure to personnel involved in the destruction of chemical weapon stockpiles or to victims of a terrorist or military attack involving these agents.

The biological fate of HD has been extensively studied [11-15] and three metabolic pathways: glutathione conjugation followed by $\beta$-lyase metabolism, hydrolysis, and direct oxidation at the sulfur atom, have been elucidated and are believed to be responsible for the HD metabolites excreted in urine [13]. Likewise, environmental degradation of HD has been well characterized $[5,16]$ and occurs primarily through hydrolysis to form thiodiglycol (TDG) and oxidation to form sulfoxides and sulfones [17]. Although the fate of sesqui- and oxy-mustards has not been as extensively studied [5, 10], these mustards are assumed to follow biological [10] and environmental pathways similar to those of HD [17, 18]. For example, D'Agostino and Provost identified several hydrolysis products in hydrolyzed 
samples of HQ and HT [18] that included diols analogous to TDG; and recently, St. Quintin et al. confirmed the hydrolysis of sesqui-mustard analogs to their respective diols using nuclear magnetic resonance spectroscopy [19]. Thus biological and environmental degradation products of HD and the analogous sesqui- and oxy-mustards include their corresponding diols TDG, bis(2-hydroxyethylthio)alkanes (BHETAs) and bis(2-hydroxyethylthioalkyl)ethers (BHETAEs), respectively.

Until relatively recently, analyses of sulfur mustards and their degradation products were performed by gas chromatography (GC) coupled to various detectors, such as flame-ionization [20] and mass spectrometry[7, 18, 21-23]. However, because mustard degradation products are more polar and less volatile than the parent CWA, analysis by GC often necessitated timeconsuming derivatization procedures that could possibly increase the complexity of the sample matrix and split the analyte signal among multiple reaction products. High-performance liquid chromatography-mass spectrometry (HPLC-MS) is more suited to the direct analysis of polar, nonvolatile compounds and reports on the analysis of sulfur mustard degradation products by this method occur in the recent literature for various ionization sources. Thermospray ionization coupled to HPLC was used in positive and negative ionization modes and revealed a tendency of the HD metabolites TDG, TDG sulfoxide (TDGSOX), and TDG sulfone (TDGSON) to form dimers at high relative abundance [24]. Not surprisingly, electrospray ionization (ESI) has been extensively evaluated as a source of ionization for sulfur mustard degradation products [6, 25-29]. Positive ESI MS at two cone voltages selected to maximize molecular ion information and to provide fragmentation data resulted in low to moderately abundant [M + $\mathrm{H}]^{+}$and $[\mathrm{M}+\mathrm{Na}]^{+}$and a base peak due to $[\mathrm{M}+\mathrm{H}-$ $\left.\mathrm{H}_{2} \mathrm{O}\right]^{+}$for TDG and TDGSON, $[\mathrm{M}+\mathrm{Na}]^{+}$was the base peak for TDGSOX [25]. Smith and Shih compared the positive ion mass spectra of HD degradation products from three different HPLC-MS interfaces: particle beam electron impact ionization (PBI), ESI and atmospheric pressure chemical ionization (APCI) [27]. Under the conditions used for these studies, Smith et al. reported PBI spectra similar to that obtained from GC-MS via electron impact ionization in that the spectra lacked a molecular ion, but contained abundant librarysearchable fragment ions; ESI and APCI resulted in [M $\left.+\mathrm{H}-\mathrm{H}_{2} \mathrm{O}\right]^{+}$as the base peak for TDG, but no APCI conditions could be found that would produce [M+ $\mathrm{H}^{+}$[27]. Other work in HPLC-APCI MS by Black and Read [30, 31] resulted in the development of rapid screening methods for the analysis of degradation products of CWA, including those of HD. For TDG, these researchers reported positive full scan mass spectra consisting of a low intensity protonated molecular ion and a base peak due to $\left[\mathrm{M}+\mathrm{H}-\mathrm{H}_{2} \mathrm{O}\right]^{+}$, and product ion spectra of $\left[\mathrm{M}+\mathrm{H}-\mathrm{H}_{2} \mathrm{O}\right]^{+}$consisting of additional product ions. The initial method was used to identify HD degradation products in soil samples collected from bomb craters in Iraq and in spiked water and soil samples [30].

The aforementioned reports focused on TDG, TDGSOX, and TDGSON, but D'Agostino et al. were the first to investigate sesqui- and oxy-mustard degradation products by HPLC-ESI MS [6, 26, 28]. These researchers developed a method to acquire positive ESI mass spectra of the hydrolysis products of Agents $Q$ and $\mathrm{T}$ that were rich in both molecular and product ion information by selecting conditions that promoted insource collision induced dissociation (CID). The resultant capillary HPLC-ESI MS method was then used to identify these compounds in aqueous samples collected from a former mustard destruction site [6]. Recently, these researchers identified the same compounds in soil extracts from a former mustard storage site using high-resolution mass spectra acquired on a quadrupole/time-of-flight mass spectrometer [26, 28]. Most recently, Tak et al. reported ESI $\mathrm{MS}^{\mathrm{n}}$ mass spectra acquired in an ion trap for all five of the sesquimustards listed on the CWC Schedule [29].

Most of the aforementioned methods produced acceptable results for the analysis of environmental samples at concentrations above $1 \mu \mathrm{g} / \mathrm{mL}$ [6, 25-29]. However, for biomonitoring purposes, a selective and sensitive analytical method for the identification and quantification of sesqui- and oxy-mustard hydrolysis products at ultra trace levels (low $\mathrm{ng} / \mathrm{mL}$ ) in biological matrices is needed. Towards this goal, our report focuses on the mass spectral behavior of the total hydrolysis products of these mustard analogs in APCI MS. APCI offers certain advantages over ESI, such as a lower susceptibility to chemical interferences [32] and ion suppression, better sensitivity due to ionization efficiencies (approaching 100\% for some compounds) [32], ruggedness[31, 32], and reliability [32]. APCI is also more suitable to typical chromatographic flow rates and, thus, is capable of providing increased sensitivity without the complications of capillary HPLC. Additionally, negative ion mode provides selective detection of analytes that form anions [31] and often results in lower background for biological samples [33]. To our knowledge, HD degradation products are the only sulfur mustard degradation products to have been analyzed by APCI MS $[27,30,31]$. Positive ion APCI MS was used to identify TDG in environmental samples and a detection limit of $\leq 10 \mathrm{ng} / \mathrm{mL}$ was reported [30, 31]. No reports on the APCI MS analysis of the hydrolysis products of the sesqui- or oxy-mustard analogs listed in the CWC Schedule were found in the literature. We examined the mass spectral characteristics of the total hydrolysis products of five sesqui- and two oxymustards under positive and negative APCI conditions and evaluated the gas-phase chemistry observed in the source for use in a selective, sensitive and rugged quantitative analytical method. 


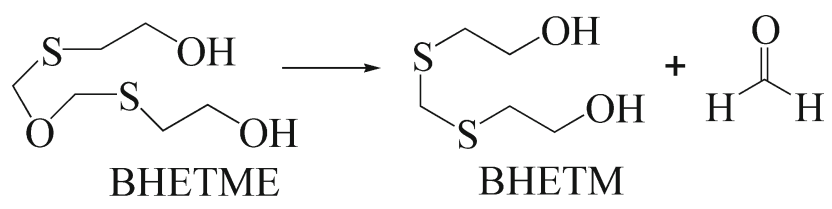

Scheme 1

\section{Experimental}

Materials

The sesqui-mustard hydrolysis products, bis(2-hydroxyethylthio)alkanes (1-5), and the oxy-mustard hydrolysis products, bis(2-hydroxyethylthioalkyl)ethers $(6,7)$ were custom synthesized (Battelle Memorial Institute, Columbus, $\mathrm{OH}$ and Cambridge Isotope Laboratories, Inc., Andover, MA) and are shown in Scheme $\mathbf{1}$ with their abbreviations. Single-analyte stock solutions were dissolved in acetonitrile then diluted in water to working concentrations of $8,80,800,2000$, and $8000 \mathrm{nM}$ $(1.6,16,160,400$, and $1600 \mathrm{ng} / \mathrm{mL}$ for BHETPr) for use in positive and negative ion experiments. All solvents were HPLC grade and were used without further purification.

\section{Mass Spectral Analyses}

APCI MS experiments were performed on an API 4000 triple quadrupole mass spectrometer (Applied Biosystems, Foster City, CA). The APCI source conditions were as follows: nebulizer current $\pm 5 \mu \mathrm{A}$ and declustering potential $\pm 23 \mathrm{~V}$, for positive/negative ionization modes, respectively; temperature $200{ }^{\circ} \mathrm{C}$; and nebulizer and curtain gas pressures at 70 and 12 psi, respectively. The first quadrupole was operated at unit resolution and scanned at $1 \mathrm{~s} / \mathrm{scan}$ over a mass range of $m / z 50$ to 460. Negative APCI tandem mass spectrometry (MS/ MS) experiments were performed at collision energies of -10 to $-12 \mathrm{eV}$ with the collision gas (nitrogen) set at six arbitrary units for an average pressure reading of 2.9 $\pm 0.1 \times 10^{-5}$ torr on the vacuum gauge. The third quadrupole was operated at unit resolution and scanned at $1 \mathrm{~s} /$ scan over a mass range of $m / z 70$ to 325 . Full scan mass spectra of individual aqueous standards were acquired by infusion into the mass spectrometer at a rate of $200 \mu \mathrm{L} / \mathrm{min}$ using a syringe pump (Harvard Apparatus, Holliston, MA).

Calibration curve standards were analyzed via LCMS/MS using an Agilent 1100 liquid chromatographic system consisting of a binary pump, autosampler, column heater, and vacuum degasser (Agilent Technologies, Wilmington, DE) interfaced to an API 4000 mass spectrometer. Individual calibrators were eluted from a Luna ${ }^{\circ} \mathrm{C} 18^{\circ}(2)^{\circ} 100^{\circ} \times{ }^{\circ} 2.1^{\circ} \mathrm{mm},{ }^{\circ} 5^{\circ} \mu \mathrm{m}^{\circ}$ column $^{\circ}$ (Phenomenex, Torrance, CA) with 60::40 water::methanol (water contained $10 \%$ methanol to reduce bacterial growth) at $200 \mu \mathrm{L} / \mathrm{min}$ to obtain calibration curve data. Ten microliters of each calibrator $(8,80,800,2000$, and 8000 $\mathrm{nM}$ ) were injected in duplicate and measured via neg- ative APCI multiple-reaction monitoring (MRM). Negative APCI MRM data were collected for three precursor/product ion transitions and provided data for construction of three five-point calibration curves for each analyte. Data generated from the calibration curves were used to assess the suitability of negative APCI MS/MS for biomonitoring purposes and to identify potential quantification and confirmation ions. A preliminary gradient separation was achieved with water plus $10 \%$ methanol (A) and methanol (B) as the mobile phase. The gradient was started at $0 \% \mathrm{~B}$ and was ramped to $25 \% \mathrm{~B}$ in $1 \mathrm{~min}$, to $55 \% \mathrm{~B}$ from 1 to $3 \mathrm{~min}$ and to $90 \%$ B from 3 to 5 min with a $10 \mathrm{~min}$ hold at $90 \%$ B for column cleaning. The mobile phase was returned to $0 \%$ B for a 3 min equilibration before the next $10-\mu \mathrm{L}$ injection. The flow rate was $400 \mu \mathrm{L} / \mathrm{min}$ and the column temperature was $45^{\circ} \mathrm{C}$.

\section{Results and Discussion}

Unambiguous identification and quantification of lowmass compounds, such as the sesqui- and oxy-mustard hydrolysis products $(\mathrm{MW}<250 \mathrm{Da})$, at the ultra-trace level in complex biological matrices, usually require multiple separation steps that include sample preparation via solid-phase extraction, HPLC, and multi-stage MS. ${ }^{\circ}$ Previous ${ }^{\circ}$ methods $^{\circ}$ relied $^{\circ}$ on ${ }^{\circ}$ in-source ${ }^{\circ} \mathrm{CID}^{\circ}[6]^{\circ}$ for production of the structurally significant fragment ions needed for reliable identification of the analytes. Although this approach may be sufficient for environmental samples, it is insufficient for complex biological matrices that often retain low-mass interferences even after multiple separation steps. To reduce the chemical noise and effectively discriminate between the analytes of interest and low-mass interferences, it is desirable to use ${ }^{\circ}$ multi-stage ${ }^{\circ} \mathrm{MS},{ }^{\circ}$ at $^{\circ} \mathrm{a}^{\circ}$ minimum ${ }^{\circ}$ of $^{\circ} \mathrm{MS}^{2}{ }^{\circ}$ [34]. Ideally, MS/MS allows measurement via MRM of a quantitative transition and at least one confirmation transition [34], ${ }^{\circ}$ thus $^{\circ}$ improving $^{\circ}$ selectivity ${ }^{\circ}$ s $^{\circ}$ well $^{\circ}$ as $^{\circ}$ sensitivity. Early experiments with ESI in our laboratory failed to produce abundant molecular ions suitable for quantification and confirmation by MRM. These results were not unexpected because alcohols do not normally protonate or deprotonate extensively during the ESI or $\mathrm{APCI}^{\circ}$ process $^{\circ}[35] . .^{\circ}$ Studies ${ }^{\circ}$ with $^{\circ}$ oxygen $^{\circ}$ have ${ }^{\circ}$ shown that the superoxide anions $\left(\mathrm{O}_{2}^{-\cdot}\right)$ produced in APCI associate with compounds containing acidic hydrogen atoms through hydrogen bonding to produce [M + $\left.\mathrm{O}_{2}\right]^{-}$as $^{\circ}$ the $^{\circ}$ major $^{\circ}$ reaction ${ }^{\circ}$ product $^{\circ}\left[36,{ }^{\circ} 37\right] .^{\circ}$ Therefore, aliphatic alcohols, such as BHETAs and BHETAEs, typically exhibit $\left[\mathrm{M}+\mathrm{O}_{2}\right]^{-}$in negative chemical ionization[36, 38]. Superoxide ${ }^{\circ}$ anions ${ }^{\circ}$ are ${ }^{\circ}$ readily ${ }^{\circ}$ produced when oxygen is present in the carrier gas at levels as low ${ }^{\circ} \mathrm{as}^{\circ} 1^{\circ} \mathrm{ppm}^{\circ}\left[39^{\circ}-42\right]$.

\section{Negative APCI Mass Spectra}

Bis(2-hydroxyethylthio)alkanes. Negative APCI full scan mass $^{\circ}$ spectra $^{\circ}$ of $^{\circ}$ the $^{\circ}$ BHETAs $^{\circ}\left(\text { Table }^{\circ} 1\right)^{\circ}$ exhibited $^{\circ}$ the 
Table 1. Ions observed in negative APCI full scan mass spectra and tandem mass spectra of bis(2-hydroxyethylthio)alkanes (BHETAs) and bis(2-hydroxyethylthioalkyl)ethers (BHETAEs) at source temperature $200{ }^{\circ} \mathrm{C}$

\begin{tabular}{|c|c|c|c|c|c|}
\hline Compound & MW & $\begin{array}{c}\text { MS ions (\% relative intensity) } \\
\text { base peak }^{\mathrm{a}}\end{array}$ & $\begin{array}{l}\text { Precursor } \\
\text { ions }\end{array}$ & Product ions ${ }^{\mathrm{b}}$ (\% relative intensity) & $\begin{array}{l}\text { Collision } \\
\text { energy }(\mathrm{eV})\end{array}$ \\
\hline \multicolumn{6}{|l|}{ BHETAs } \\
\hline BHETM & 168 & $\begin{array}{c}\text { 200(100), 167(7), 165(3), 123(21), } \\
121(19), 105(23), 77(48)\end{array}$ & $\begin{array}{l}200 \\
167\end{array}$ & $\begin{array}{l}200(100), 167(28), 149(2), 123(70), 77(2) \\
167(57), 149(100), 123(9), 105(15), 77(3)\end{array}$ & -9 \\
\hline BHETE & 182 & $\begin{array}{l}\text { 214(100), 181(11), 179(11), 137(8), } \\
\text { 135(8), 77(56) }\end{array}$ & $\begin{array}{l}214 \\
181\end{array}$ & $\begin{array}{l}214(100), 181(36), 137(45), 77(19) \\
181(4), 137(1), 77(100)\end{array}$ & -10 \\
\hline BHETPr & 196 & $\begin{array}{c}\text { 228(100), 195(12), 193(11) } \\
151(13), 149(8), 77(43)\end{array}$ & $\begin{array}{l}228 \\
195\end{array}$ & $\begin{array}{l}\text { 228(100), 195(17), 151(25), 77(3) } \\
\text { 195(9), 77(100) }\end{array}$ & -10 \\
\hline BHETB & 210 & $\begin{array}{l}\text { 242(100), 209(13), 207(9), 165(8), } \\
\text { 163(11), 77(47) }\end{array}$ & $\begin{array}{l}242 \\
209\end{array}$ & $\begin{array}{l}\text { 242(100), 209(22), 165(19), 77(1) } \\
209(91), 165(2), 77(100)\end{array}$ & -10 \\
\hline BHETPn & 224 & $\begin{array}{c}256(100), 223(31), 221(13) \\
179(12), 177(13), 77(48)\end{array}$ & $\begin{array}{l}256 \\
223\end{array}$ & $\begin{array}{l}256(100), 223(62), 179(32), 77(1) \\
223(100), 179(7), 77(75)\end{array}$ & -12 \\
\hline \multicolumn{6}{|l|}{ BHETAEs } \\
\hline BHETME & 198 & $\begin{array}{l}\text { 230(100), 200(20), 197(13), } \\
\text { 123(24), 121(32), 105(36), } \\
\text { 77(94) }\end{array}$ & $\begin{array}{l}230 \\
200 \\
197\end{array}$ & 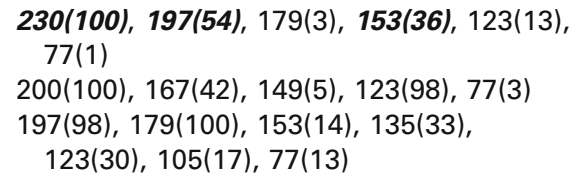 & -10 \\
\hline BHETEE & 226 & $\begin{array}{c}258(100), 225(27), 223(14), 181(9), \\
179(7), 121(19), 77(61), 75(30)\end{array}$ & $\begin{array}{l}258 \\
225\end{array}$ & $\begin{array}{l}\text { 258(99), 225(100), 181(38), 121(62) } \\
225(5), 121(100), 103(16), 77(1)\end{array}$ & -12 \\
\hline
\end{tabular}

aBold indicates base peak.

${ }^{\mathrm{b}}$ Bold and italic indicate precursor/product ion transitions measured via multiple-reaction monitoring for construction of calibration curves.

superoxide adduct, $\left[\mathrm{M}+\mathrm{O}_{2}\right]^{-}$, the deprotonated molecular ions, $[\mathrm{M}-\mathrm{H}]^{-}$and $[\mathrm{M}-3 \mathrm{H}]^{-}$, and fragment ions produced by in-source CID. Under the experimental conditions used here, $\left[\mathrm{M}+\mathrm{O}_{2}\right]^{-}$was the base peak with abundances consistent with those reported by Hunt ${ }^{\circ} \mathrm{et}^{\circ}{ }^{\circ}{ }^{\circ}{ }^{\circ}$ for ${ }^{\circ}$ aliphatic ${ }^{\circ}$ alcohols ${ }^{\circ}[36]^{\circ}{ }^{\circ}$ However, ${ }^{\circ}$ as ${ }^{\circ}$ the source temperature was increased above $200{ }^{\circ} \mathrm{C}$, the intensities of $\left[\mathrm{M}+\mathrm{O}_{2}\right]^{-}$and $[\mathrm{M}-\mathrm{H}]^{-}$decreased and the intensities of lower mass fragment ions increased. The origin of the fragment ions produced by in-source
CID was confirmed by product ion scans of $\left[\mathrm{M}+\mathrm{O}_{2}\right]^{-}$, $[\mathrm{M}-\mathrm{H}]^{-}$and $[\mathrm{M}-3 \mathrm{H}]^{-}$. These fragments (shown in Figure ${ }^{\circ}{ }^{\circ}$ for $\left.^{\circ} \mathrm{BHETPr}\right)^{\circ}$ may $^{\circ} \mathrm{be}^{\circ}$ attributed ${ }^{\circ}$ to ${ }^{\circ}$ the ${ }^{\circ}$ elimination of small neutral molecules such as $\left[\mathrm{M}+\mathrm{O}_{2}-\right.$ $\left.\mathrm{HO}_{2}\right]^{-}$that results in $[\mathrm{M}-\mathrm{H}]^{-} .\left[\mathrm{M}-\mathrm{H}-\mathrm{C}_{2} \mathrm{H}_{4} \mathrm{O}\right]^{-}$and $\left[\mathrm{M}-\mathrm{H}-\mathrm{S}\left(\mathrm{CH}_{2}\right)_{n} \mathrm{C}_{2} \mathrm{H}_{4} \mathrm{O}\right]^{-}$may account for [M $45]^{-}$and a common ion at $\mathrm{m} / \mathrm{z} 77$, respectively, where " $n$ " equals the number of methylene groups between the sulfur atoms. In addition, a neutral loss of $\mathrm{H}_{2}$ from $[\mathrm{M}-\mathrm{H}]^{-}$could result in $[\mathrm{M}-3 \mathrm{H}]^{-}$. Consequently, $[\mathrm{M}$

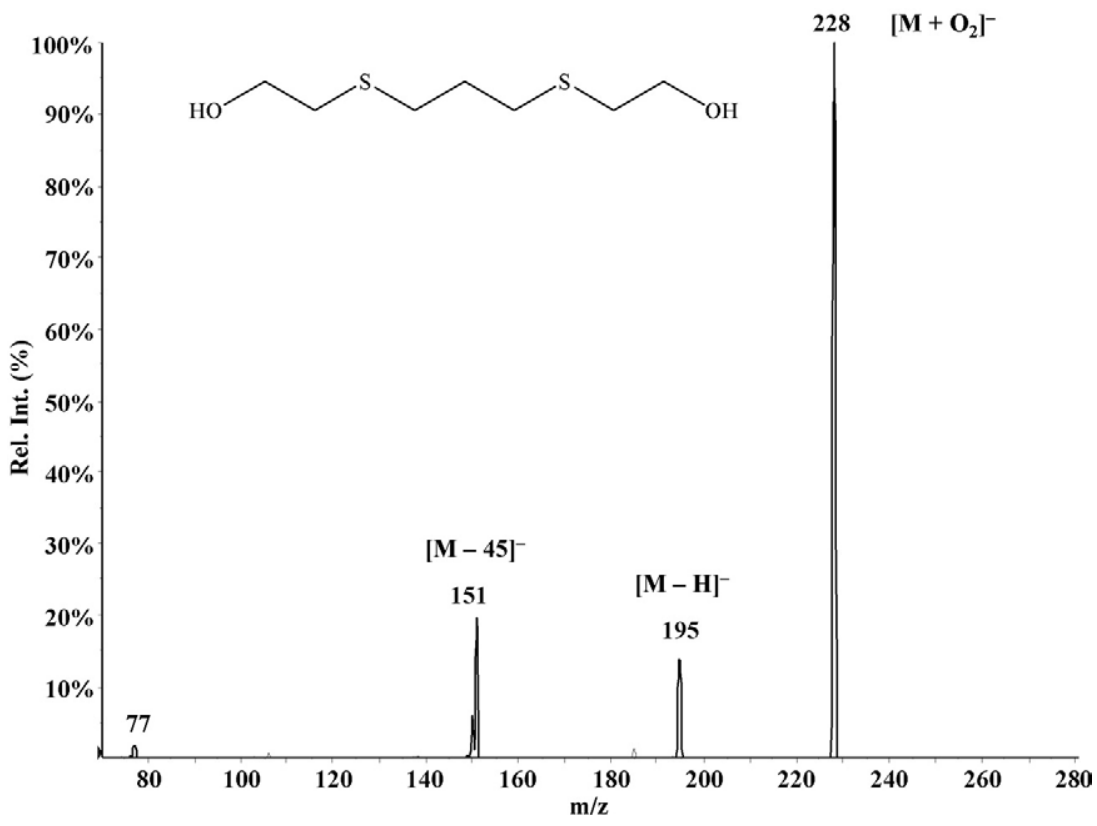

Figure 1. Product ion spectrum of $\left[\mathrm{M}+\mathrm{O}_{2}\right]^{-}$of bis(2-hydroxyethylthio)propane (BHETPr, nominal mass 196) obtained with the collision energy at $-10 \mathrm{eV}$ and collision gas (nitrogen) at $2.9 \times 10^{-5}$ torr. 


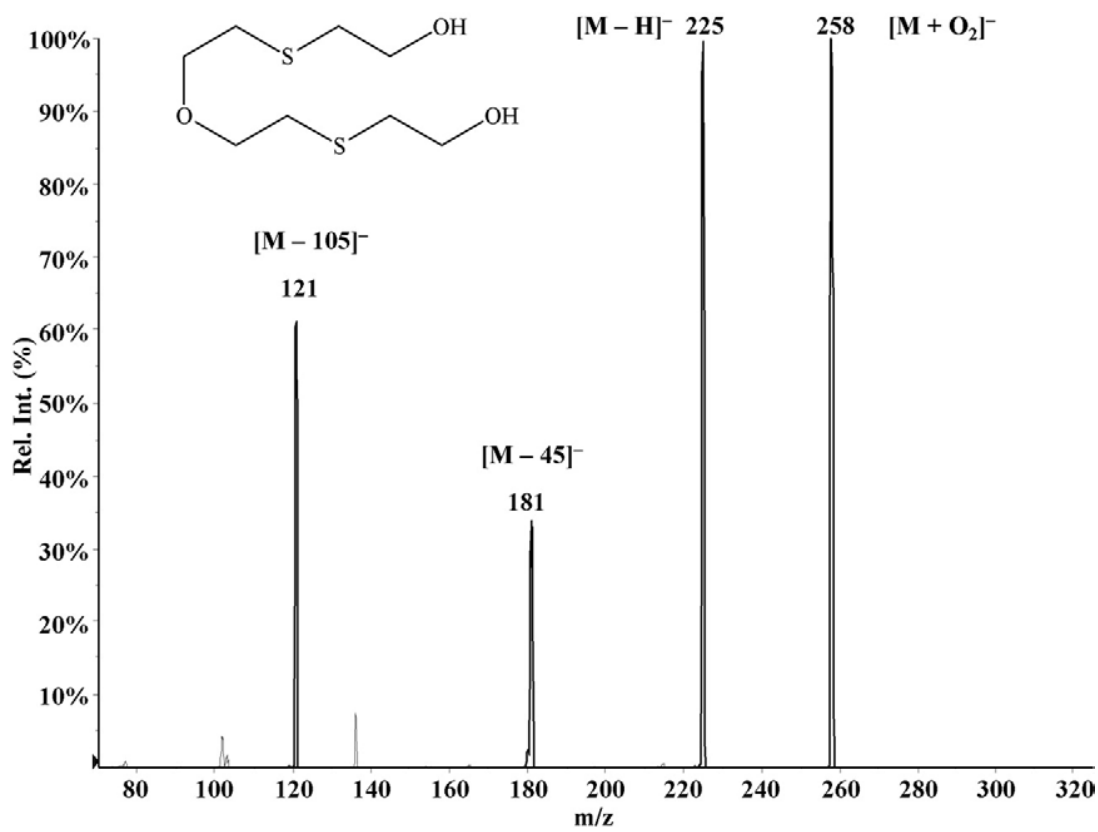

Figure 2. Product ion spectrum of $\left[\mathrm{M}+\mathrm{O}_{2}\right]^{-}$of bis(2-hydroxyethylthioethyl)ether (BHETEE, nominal mass 226) obtained with the collision energy at $-12 \mathrm{eV}$ and collision gas (nitrogen) at $2.9 \times$ $10^{-5}$ torr.

$\left.-3 \mathrm{H}-\mathrm{C}_{2} \mathrm{H}_{4} \mathrm{O}\right]^{-}$could account for $[\mathrm{M}-47]^{-}$present in the MS and MS/MS spectra of $[\mathrm{M}-3 \mathrm{H}]^{-}$and $[\mathrm{M}-3 \mathrm{H}$ $\left.-\mathrm{S}\left(\mathrm{CH}_{2}\right)_{n} \mathrm{C}_{2} \mathrm{H}_{4} \mathrm{O}\right]^{-}$may account for $m / z 75$ observed in

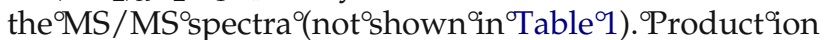
scans also showed additional ions at $\mathrm{m} / \mathrm{z} 149$ and $\mathrm{m} / \mathrm{z}$ 105 for BHETM that appear to be due to $\left[\mathrm{M}-\mathrm{H}-\mathrm{H}_{2} \mathrm{O}\right]^{-}$ and $\left[\mathrm{M}-\mathrm{H}-\mathrm{H}_{2} \mathrm{O}-\mathrm{C}_{2} \mathrm{H}_{4} \mathrm{O}\right]^{-}$. The ion at $\mathrm{m} / z 105$ was present in both the in-source CID and product ion spectra, however, analogous product ions were present only at very low abundances for the other BHETAs. Although these fragment ions may be rationalized in terms of eliminations of small neutral molecules, the resulting anion structures are unknown for molecules with this many heteroatoms.

Bis(2-hydroxyethylthioalkyl)ethers. The oxy-mustard hydrolysis products, BHETAEs exhibited negative APCI mass ${ }^{\circ}$ spectra ${ }^{\circ}\left(\text { Table }^{\circ}\right)^{\text {othat }}{ }^{\circ}$ consisted $^{\circ}$ of the $^{\text {base }}$ peak at $\left[\mathrm{M}+\mathrm{O}_{2}\right]^{-},[\mathrm{M}-\mathrm{H}]^{-}$, and additional ions due to in-source CID. In the case of BHETEE, the in-source CID spectrum was similar to that of the analogous sesquimustard hydrolysis product, BHETE, except that additional ions were observed in both the in-source CID and product $^{\circ}$ ion $^{\circ}$ mass $^{\circ}$ spectra $^{\circ}$ of $^{\circ} \mathrm{BHETEE}^{\circ}\left(\right.$ Figure $\left.^{\circ} 2\right) .{ }^{\circ}$ One additional ion at $m / z 121$ is analogous to $m / z 77$ for the BHETAs and likewise was attributed to a neutral loss of $\left[\mathrm{M}-\mathrm{H}-\mathrm{SC}_{2} \mathrm{H}_{4} \mathrm{OC}_{2} \mathrm{H}_{4}\right]^{-}$. This ion was present in the in-source CID mass spectrum of BHETEE and was confirmed by MS/MS of $\left[\mathrm{M}+\mathrm{O}_{2}\right]^{-}$and $[\mathrm{M}-\mathrm{H}]^{-}$. An ion at $\mathrm{m} / \mathrm{z} 103$ was only exhibited in product ion scans and may be attributed to loss of water from $m / z 121$. A common ion at $\mathrm{m} / \mathrm{z} 77$ was also observed for the BHETAEs and may be accounted for by $[\mathrm{M}-\mathrm{H}-$
$\left.\mathrm{OC}_{2} \mathrm{H}_{4} \mathrm{SC}_{2} \mathrm{H}_{4} \mathrm{OC}_{2} \mathrm{H}_{4}\right]^{-}$. These results are consistent with the fragmentation patterns of the related BHETAs while accounting for the additional $\left(\mathrm{CH}_{2}\right)_{\mathrm{n}} \mathrm{O}\left(\mathrm{CH}_{2}\right)_{\mathrm{n}}$ moiety of the BHETAEs. As in the case of BHETAs, the fragment ions may be accounted for by the loss of small neutral molecules, but the resulting anion structures are unknown.

In addition to $\left[\mathrm{BHETME}+\mathrm{O}_{2}\right]^{-}$at $m / z$ 230, the negative ion mass spectrum of BHETME exhibited an ion at $m / z 200$ as well as other ions of the same $m / z$ as those present in the mass spectrum of the analogous sesqui-mustard ${ }^{\circ}$ hydrolysis $^{\circ}$ product $^{\circ}$ BHETM $^{\circ}\left(\right.$ Table $\left.^{\circ} 1\right)$. Furthermore, MS/MS of $\mathrm{m} / \mathrm{z} 200$ resulted in the same product ions with similar relative intensities as those observed in the MS/MS spectrum of [BHETM $\left.+\mathrm{O}_{2}\right]^{-}$ (Figure $\left.{ }^{\circ} 3\right) .{ }^{\circ}$ In $^{\circ}$ contrast, $^{\circ}$ the ${ }^{\circ}$ product $^{\circ}$ ion $^{\circ}$ mass $^{\circ}$ spectra $^{\circ}$ of $m / z 230$ and $m / z 197$ from BHETME exhibited ions analogous to the product ions observed for $m / z 200$ and $m / z 167$ from BHETM as well as product ions at the same $m / z$ as those from BHETM. BHETME product ions at $m / z 179, m / z 153$ and $m / z 135$ may be accounted for by $\left[\mathrm{M}-\mathrm{H}-\mathrm{H}_{2} \mathrm{O}\right]^{-},\left[\mathrm{M}-\mathrm{H}-\mathrm{C}_{2} \mathrm{H}_{4} \mathrm{O}\right]^{-}$and $\left[\mathrm{M}-\mathrm{H}-\mathrm{H}_{2} \mathrm{O}\right.$ $\left.-\mathrm{C}_{2} \mathrm{H}_{4} \mathrm{O}\right]^{-}$, respectively. These results suggest that $\mathrm{m} / \mathrm{z}$ 200 may be attributed to [BHETM $\left.+\mathrm{O}_{2}\right]^{-}$derived from BHETME. GC-MS data for BHETME acquired during purity assessment of the synthesized compounds at Battelle, led Battelle scientists to suggest that the molecule may undergo a thermally activated intra-molecular rearrangement with the elimination of formaldehyde (30 Da) to form BHETM (Scheme 2) (George Emmett, Battelle, business communication). Our observations appear to support this suggested rearrangement. 


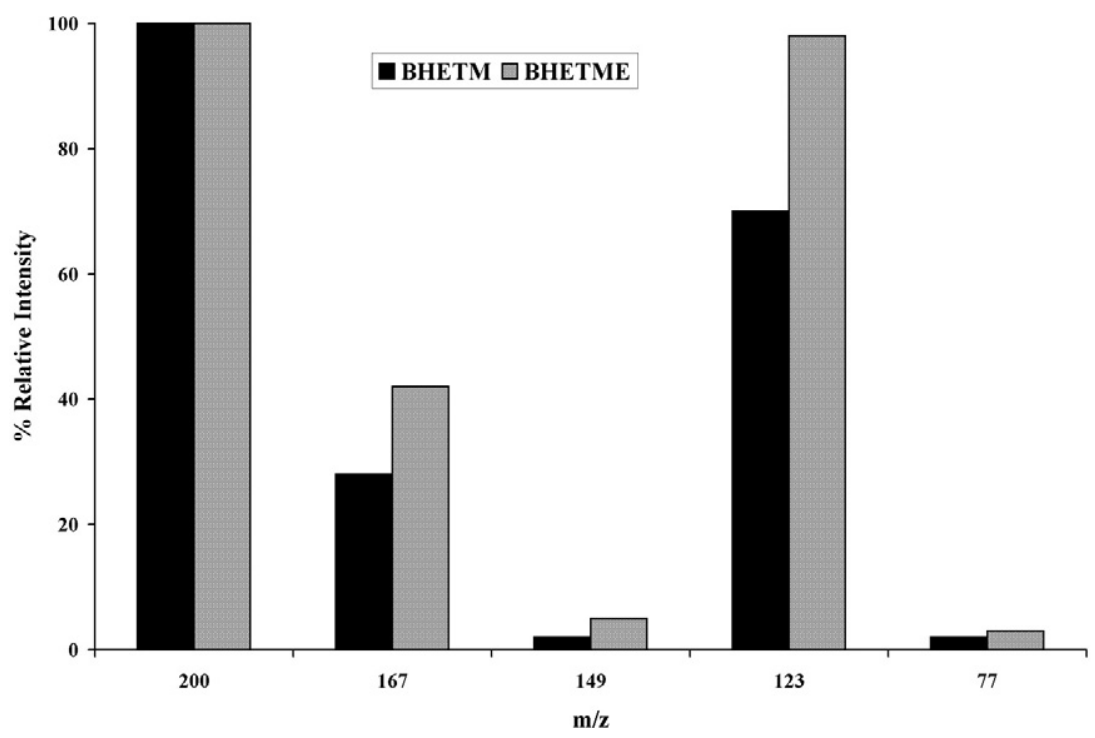

Figure 3. Comparison of the relative intensities of the product ions of the precursor ions at $\mathrm{m} / \mathrm{z} 200$ originating from negative APCI of bis(2-hydroxyethylthio)methane (BHETM) and of bis(2-hydroxyethylthiomethyl)ether (BHETME) as evidence of rearrangement.

\section{Positive APCI Mass Spectra}

Bis(2-hydroxyethylthio)alkanes. Positive APCI full scan mass $^{\circ}$ spectra ${ }^{\circ}$ of ${ }^{\circ}$ the ${ }^{\circ} \mathrm{BHETAs}^{\circ}\left(\text { Table }^{\circ} 2\right)^{\circ}{ }^{\circ}$ consisted $^{\circ}$ of ${ }^{\circ}$ the protonated, $[\mathrm{M}+\mathrm{H}]^{+}$, molecular ion and fragment ions produced by in-source CID. Product ion mass spectra of $[\mathrm{M}+\mathrm{H}]^{+}$exhibited the same fragment ions as in-source CID, thus confirming their origin. Fragments were attributed to neutral losses such as $\left[\mathrm{M}+\mathrm{H}-\mathrm{H}_{2} \mathrm{O}\right]^{+}$, [M $\left.+\mathrm{H}-\mathrm{H}_{2} \mathrm{O}-\mathrm{C}_{2} \mathrm{H}_{4}\right]^{+}$and $\left[\mathrm{M}+\mathrm{H}-\mathrm{H}_{2} \mathrm{O}-\mathrm{SC}_{2} \mathrm{H}_{4}\right]^{+}$. Under the experimental conditions used, the base peak for the shorter chain compounds BHETM and BHETE was $[\mathrm{M}+\mathrm{H}]^{+}$; and the base peak for the longer chain compounds BHETPr, BHETB, and BHETPn was the fragment ion $\left[\mathrm{M}+\mathrm{H}-\mathrm{H}_{2} \mathrm{O}-\mathrm{C}_{2} \mathrm{H}_{4}\right]^{+}$. Product ion scans of $\left[\mathrm{M}+\mathrm{H}-\mathrm{H}_{2} \mathrm{O}-\mathrm{C}_{2} \mathrm{H}_{4}\right]^{+}$from BHETPr, BHETB and BHETPn resulted in additional product ions that may be accounted for by further neutral losses of $\mathrm{C}_{2} \mathrm{H}_{4} \mathrm{O}$ and $\mathrm{H}_{2} \mathrm{~S}$. APCI MS and MS/MS spectra agree with $\mathrm{MS}^{\mathrm{n}}$<smiles>OCCSCCO</smiles><smiles>OCCSCCO[Pb]1COCCO1</smiles>

$$
\begin{aligned}
& \mathrm{n}=1, \text { BHETM } \\
& \mathrm{n}=2, \text { BHETE } \\
& \mathrm{n}=3 \text {, BHETPr } \\
& \mathrm{n}=4 \text { (3) BHETB } \\
& \mathrm{n}=5, \text { BHETPn (5) }
\end{aligned}
$$

$$
\begin{aligned}
& n=1, \operatorname{BHETME~(6)} \\
& n=2, \operatorname{BHETEE~(7)}
\end{aligned}
$$

Scheme 2. Proposed rearrangement of bis(2-hydroxyethylthiomethyl)ether (BHETME) to bis(2-hydroxyethylthio)methane (BHETM) through loss of formaldehyde (George Emmett, Battelle, business communication). spectra and fragmentation routes suggested by Tak et al. ${ }^{\circ}[29]$.

Bis(2-hydroxyethylthioalkyl)ethers. Oxy-mustard hydrolysis product BHETEE exhibited a positive APCI mass $\operatorname{spectrum}^{\circ}\left(\text { Table }^{\circ} 2\right)^{\circ}$ similar $^{\circ}$ to $^{\circ}$ that $^{\circ}$ of $^{\circ}$ the ${ }^{\circ}$ analogous sesqui-mustard hydrolysis product BHETE. However, for BHETEE, $\left[\mathrm{M}+\mathrm{H}-\mathrm{H}_{2} \mathrm{O}\right]^{+}$was the base peak. Both in-source CID and product ion mass spectra of BHETEE resulted in an additional ion at $\mathrm{m} / \mathrm{z} 105$ that may be accounted for by $\left[\mathrm{M}+\mathrm{H}-\mathrm{H}_{2} \mathrm{O}-\mathrm{SC}_{2} \mathrm{H}_{4} \mathrm{OC}_{2} \mathrm{H}_{4}\right]^{+}$. As in negative ion APCI, these results are consistent with the fragmentation patterns of the related BHETAs while accounting for the additional $\left(\mathrm{CH}_{2}\right)_{\mathrm{n}} \mathrm{O}\left(\mathrm{CH}_{2}\right)_{\mathrm{n}}$ moiety of the BHETAEs.

The $^{\circ}$ positive ${ }^{\circ} \mathrm{APCI}^{\circ}$ mass $^{\circ}$ spectrum $^{\circ}\left(\text { Table }^{\circ} 2\right)^{\circ}$ of ${ }^{\circ}$ the oxy-mustard hydrolysis product BHETME differed from that of the other oxy- and sesqui-mustard hydrolysis products. Instead of the expected $[\mathrm{M}+\mathrm{H}]^{+}$at $m / z$ 199, BHETME exhibited a low intensity ion at $\mathrm{m} / \mathrm{z} 181$ due to $\left[\mathrm{M}+\mathrm{H}-\mathrm{H}_{2} \mathrm{O}\right]^{+}$. Lower mass ions were also observed that exhibited the same $\mathrm{m} / \mathrm{z}$ and similar relative intensities as ions observed in the mass spectrum of the analogous sesqui-mustard hydrolysis product BHETM. A product ion scan of the base peak of BHETME at $m / z 169$ resulted in a spectrum similar to that of $\mathrm{m} / \mathrm{z} 169$ from BHETM both in the product ions observed $^{\circ}{ }^{\circ}{ }^{\circ}{ }^{\circ}$ their $^{\circ}$ relative $^{\circ}$ intensities ${ }^{\circ}\left(\right.$ Figure $\left.^{\circ} 4\right)$. ${ }^{\circ}$ These results suggest that $m / z 169$ may be due to $[\mathrm{M}+\mathrm{H}]^{+}$of BHETM, accordingly, the ion at $m / z 169$ and the product ions at $m / z 151, m / z 123$ and $m / z 91$ were assigned to [M $+\mathrm{H}]^{+}$of BHETM derived from BHETME. This evidence further suggests that BHETME may undergo an intra-molecular rearrangement with the elimination of formaldehyde to form BHETM as discussed under the negative ion results for BHETME. 
Table 2. Ions observed in positive APCI full scan mass spectra and tandem mass spectra of bis(2-hydroxyethylthio)alkanes (BHETAs) and bis(2-hydroxyethylthioalkyl)ethers (BHETAEs) at source temperature $200^{\circ} \mathrm{C}$ unless otherwise noted

\begin{tabular}{|c|c|c|c|c|c|}
\hline Compound & MW & $\begin{array}{l}\text { MS lons (Mean \%relative } \\
\text { intensity) base peak }\end{array}$ & $\begin{array}{l}\text { Precursor } \\
\text { ions }\end{array}$ & $\begin{array}{l}\text { Product ions (\%relative } \\
\text { intensity) }\end{array}$ & $\begin{array}{l}\text { Collision } \\
\text { energy }(\mathrm{eV})\end{array}$ \\
\hline \multicolumn{6}{|l|}{ BHETAs } \\
\hline BHETM & 168 & 169(100), 151(33), 123(37), 91(18) & 169 & 169(10), 151(10), 123(3), 91(100) & 9 \\
\hline BHETE & 182 & $\begin{array}{l}\text { 183(100), 165(33), 137(15), } \\
105(38)\end{array}$ & 183 & $183(3), 165(10), 137(22), 105(100)$ & 10 \\
\hline BHETPr & 196 & 197(50), 179(3), 151(100) & $\begin{array}{l}197 \\
151\end{array}$ & $\begin{array}{l}197(1), 179(<1), 151(100), 119(3) \\
151(100), 107(7), 73(<1)\end{array}$ & 11 \\
\hline $\begin{array}{l}\text { BHETB } \\
@ 300^{\circ} \mathrm{C}\end{array}$ & 210 & $\begin{array}{l}211(28), 193(12), 165(100), \\
133(46)\end{array}$ & $\begin{array}{l}211 \\
165\end{array}$ & $\begin{array}{l}211(10), 193(2), 165(100), 133(25) \\
165(100), 121(22), 87(9)\end{array}$ & $\begin{array}{l}10 \\
15\end{array}$ \\
\hline BHETPn & 224 & $\begin{array}{l}225(30), 207(72), 179(100), \\
147(21)\end{array}$ & $\begin{array}{l}225 \\
179\end{array}$ & $\begin{array}{l}225(2), 207(10), 179(100), 147(18) \\
179(100), 135(1), 101(42)\end{array}$ & 12 \\
\hline \multicolumn{6}{|l|}{ BHETAEs } \\
\hline BHETME & 198 & $\begin{array}{l}\text { 181(18), 169(100), 151(38), } \\
\text { 123(79), 91(21) }\end{array}$ & $\begin{array}{l}181 \\
169\end{array}$ & $\begin{array}{l}\text { 181(91), 91(100) } \\
169(12), 151(11), 123(4), 91(100)\end{array}$ & 9 \\
\hline $\begin{array}{l}\text { BHETEE } \\
@ 300^{\circ} \mathrm{C}\end{array}$ & 226 & $\begin{array}{l}\text { 227(64), 209(100), 181(7), 149(9), } \\
105(84)\end{array}$ & $\begin{array}{l}227 \\
209\end{array}$ & $\begin{array}{l}227(5), 209(68), 181(20), 105(100) \\
209(100), 181(48), 149(2)\end{array}$ & 12 \\
\hline
\end{tabular}

aBold indicates base peak.

\section{Evaluation of Superoxide Adduct for Quantitative Analysis}

Superoxide addition complexes formed through nucleophilic attack by $\mathrm{O}_{2}{ }^{-\cdot}$ are ${ }^{\circ}$ stable $[37]^{\circ}$ and ${ }^{\circ}$ effectively increase the molecular mass in a manner similar to post-column derivatization. This mass shift could move the analytes away from potential isobaric matrix interferences without the use of additional reagents that could compete with the analytes for ionization. Solely for the purpose of determining whether the superoxide adduct would be stable and would provide a linear calibration curve over our typical calibration range, we acquired data over two days for five calibrants $(8 \mathrm{nM}$, $80 \mathrm{nM}, 800 \mathrm{nM}, 2000 \mathrm{nM}$, and $8000 \mathrm{nM}$ ). Three ion transitions of the precursor ion $\left[\mathrm{M}+\mathrm{O}_{2}\right]^{-}$that produced the highest masses and greatest relative abundances were selected and measured via MRM. For BHETAs and BHETME, the ions monitored were $[\mathrm{M}+$ $\left.\mathrm{O}_{2}\right]^{-},\left[\mathrm{M}+\mathrm{O}_{2}-33\right]^{-}$, and $\left[\mathrm{M}+\mathrm{O}_{2}-77\right]^{-}$; but for BHETEE, the third product ion selected was $\left[\mathrm{M}+\mathrm{O}_{2}-\right.$ $137]^{-}{ }^{\circ}\left(\right.$ Table $\left.^{\circ} 1\right) .{ }^{\circ}{ }^{\circ}$ Calibration ${ }^{\circ}$ curves $^{\circ}$ of $^{\circ}$ observed $^{\circ}$ peak height versus expected concentration were constructed from duplicate data points at each concentration level. Separate calibration curves were produced from each of the three transitions monitored on each day, resulting in a total of six calibration curves per analyte. For all analytes, linear regression analysis with $1 / x$ weighting produced linear $\left(r^{2} \geq 0.9946\right)$ calibration curves for all

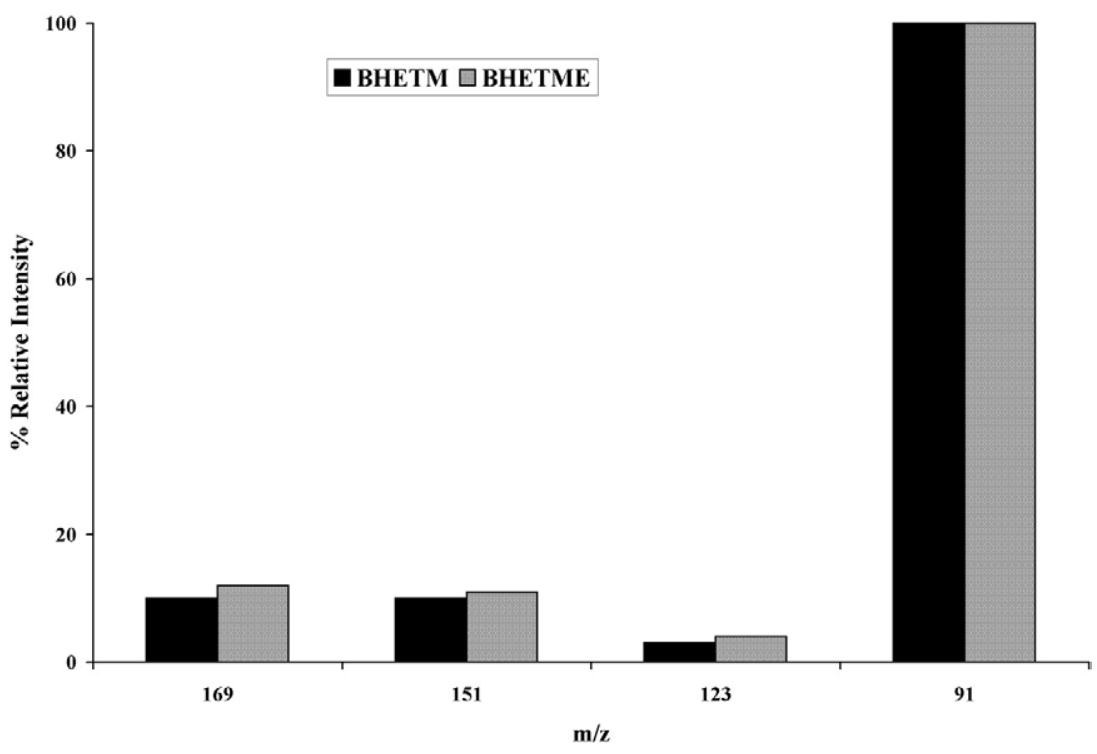

Figure 4. Comparison of the relative intensities of the product ions of the precursor ions at $\mathrm{m} / \mathrm{z} 169$ originating from positive APCI of bis(2-hydroxyethylthio)methane (BHETM) and of bis(2-hydroxyethylthiomethyl)ether (BHETME) as evidence of rearrangement. 
transitions over at least two orders of magnitude (from 80 to $8000 \mathrm{nM}$ ) with relative standard errors of the estimate (RSEE) of $<10 \%$. For BHETEE, the linear range (RSEE $<15 \%$ ) was extended to three orders of magnitude (from 8 to $8000 \mathrm{nM}$ ). The lowest calibrant $(8 \mathrm{nM}$ ) was not included in the calibration curves for the other analytes because signals were less than three times the signal-to-noise.

Analytical figures of merit for each calibrant were estimated for each transition from the calibration curve data. Accuracy of the calibrants was evaluated in terms of the percentage of the mean calculated concentration for four injections $(n=4)$ divided by the expected concentration. Likewise, run-to-run precision of the calibrants was evaluated by calculating the relative standard deviation (RSD) of the calculated concentrations $(n=4)$. Calibrants at $80,800,2000$, and $8000 \mathrm{nM}$ ( 15 to $1500 \mathrm{ng} / \mathrm{mL}$ ) for all analytes, and at $8 \mathrm{nM}(1.8$ $\mathrm{ng} / \mathrm{mL}$ ) for BHETEE only were found to have individual accuracies between $89 \%$ and $113 \%$ and individual run-to-run precision $<15 \%$ RSD for all transitions. For quantitative analysis at ultra-trace levels, these accura-

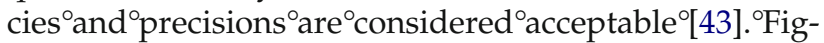
ures of merit were roughly estimated from a few experiments rather than rigorously determined because our only intent was to assess the feasibility of developing a quantitative mass spectrometry method predicated on the superoxide adduct rather than to perform a complete validation. Limitations of this report therefore include the low number of quantitative experiments performed, the lack of internal standards and the number and distribution of calibrants across a wide dynamic range. Despite these limitations, all analytes exhibited linear calibration curves and acceptable overall figures of merit for the 80, 800, 2000, and $8000 \mathrm{nM}$ ( 15 to $1500 \mathrm{ng} / \mathrm{mL}$ ) standard levels as calculated from four-point calibration curves. Additionally, BHETEE exhibited acceptable figures of merit for the $8 \mathrm{nM}$ standard level as calculated from linear five-point calibration curves, thus extending the dynamic range to three orders of magnitude for this analyte. Thus individual figures of merit indicated the potential for a quantification ion and two confirmation ions per analyte for concentrations at least as low as $80 \mathrm{nM}$ (13 to 18 $\mathrm{ng} / \mathrm{mL})$ and $8 \mathrm{nM}(1.8 \mathrm{ng} / \mathrm{mL})$ for BHETEE. This result illustrates the exceptional response of BHETEE compared with the other analytes. For the purposes of this report, the instrument limit of detection (LOD) and limit of quantitation (LOQ) were calculated as $3 \mathrm{~S}_{0}$ and $10 S_{0}$, respectively, where $S_{0}$ is "the value of the standard deviation as ${ }^{\circ}$ the ${ }^{\circ}$ concentration approaches ${ }^{\circ}$ zero $^{\prime \prime}[43] .{ }^{\circ} S_{0}$ was estimated at 95\% CL as the y-intercept of the linear regression of the estimated standard deviations of three calibrators $^{\circ}$ versus $^{\circ}$ their $^{\circ}$ expected $^{\circ}$ concentrations $^{\circ}[43]$. LODs based on $\mathrm{S}_{0}$ estimated from this method agree with the experimental results in that the calculated LODs are between the lowest calibrator that was accurately measured and the lowest calibrator analyzed, but not ${ }^{\circ}$ detected.$^{\circ}$ For $^{\circ}$ brevity, ${ }^{\circ}$ the ${ }^{\circ}$ data ${ }^{\circ}$ presented ${ }^{\circ}{ }^{\circ}{ }^{\circ}$ Table $^{\circ} 3$ represents figures of merit for observations derived from the product of four analyses and three precursor/ product ion transitions. BHETM and BHETEE, at their lowest concentrations, show 11 rather than 12 observations because no peak was detected for one of the transitions.

Individual standards were injected for the calibration curve data and chromatographed separately under isocratic conditions. After the evaluation of the calibration curve data, a preliminary gradient elution was developed on the same column. High aqueous content in the initial mobile phase was necessary to sufficiently retain the lower molecular weight analytes. Formic acid could not be used in the mobile phase to improve peak shape, because formic acid interfered with formation of $\left[\mathrm{M}+\mathrm{O}_{2}\right]^{-}$. The slower gradient from 1 to $3 \mathrm{~min}$ was necessary to adequately separate the BHETAEs from BHETE and BHETPr so that competition for ionization from closely eluting compounds would be minimized. Figure ${ }^{\circ}{ }^{\circ}$ shows $^{\circ}$ the ${ }^{\circ}$ extracted ${ }^{\circ}$ ion ${ }^{\circ}$ chromatograms ${ }^{\circ}$ of ${ }^{\circ}$ the lowest intensity precursor/product ion pair at the lowest concentration level ( $8 \mathrm{nM}$ for BHETEE; $80 \mathrm{nM}$ for all other analytes) for each analyte. With the preliminary gradient, the sesqui-mustard metabolites are well resolved $\left(R_{s} \geq 2.5\right)$ from each other and the oxy-mustard metabolites are baseline resolved $\left(R_{s}=1.5\right)$ from each other. However, the oxy-mustard metabolites elute between BHETE and BHETPr, so that the resolution between BHETE and BHETME is baseline $\left(R_{s}=1.6\right)$ and the resolution between BHETEE and BHETPr is less than baseline $\left(R_{\mathrm{s}}=1.2\right)$. Further adjustment of the gradient and other chromatographic parameters may be necessary to adjust for matrix interferences in urine or environmental samples.

\section{Conclusions}

Bis(2-hydroxyethylthio)alkanes (BHETAs) and bis(2hydroxyethylthioalkyl)ethers (BHETAEs) are important environmental and biological markers of sesquiand oxy-mustard vesicants that are listed on the Chemical Warfare Convention Schedule of Chemicals. ${ }^{\circ}$ Although ${ }^{\circ}$ other $^{\circ}{ }^{\text {researchers }}{ }^{\circ}\left[6,{ }^{\circ} 26,{ }^{\circ} 28,{ }^{\circ} 29\right]^{\circ}$ have been able to quantify these compounds in positive ESI MS to $1 \mu \mathrm{g} / \mathrm{mL}$, early experiments in our laboratory using standard materials in this concentration range resulted in $[\mathrm{M}+\mathrm{Na}]^{+}$and $[\mathrm{M}+\mathrm{K}]^{+}$ions of greater relative abundances than $[\mathrm{M}+\mathrm{H}]^{+}$. Such adduct formation is generally observed more often in ESI than in APCI, with alkali metal ions exhibiting a strong affinity for oxygenated centers such as those in

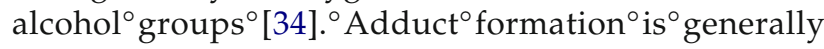
undesirable because it reduces sensitivity by splitting the analyte signal among multiple species and adducts ${ }^{\circ}$ are $^{\circ}$ less $^{\circ}$ amenable $^{\circ}$ to $^{\circ} \mathrm{MS} / \mathrm{MS}^{\circ}\left[27{ }^{\circ},{ }^{\circ}\right.$ often ${ }^{\circ}$ resulting in product ion spectra consisting mostly of the adducted ion (i.e., $\mathrm{Na}^{+}$or $\mathrm{K}^{+}$). Because insufficient fragmentation and poor reproducibility limit the use of ${ }^{\circ}$ lkali ${ }^{\circ}$ metal ${ }^{\circ}$ adducts $^{\circ}$ for ${ }^{\circ}$ quantitative $^{\circ}$ purposes [34], 
Table 3. Figures of merit for bis(2-hydroxyethylthio)alkanes (BHETAs) and bis(2-hydroxyethylthioalkyl)ethers (BHETAEs) at given standard levels. The results shown were averaged over three ion transitions ${ }^{\mathrm{a}}$ measured from duplicate injections on each of 2 days

\begin{tabular}{|c|c|c|c|c|c|c|c|c|}
\hline \multirow[b]{2}{*}{ Compound } & \multirow{2}{*}{$\begin{array}{c}\text { No. of } \\
\text { observations }\end{array}$} & \multicolumn{2}{|c|}{$\begin{array}{c}\text { Expected } \\
\text { concentration }\end{array}$} & \multirow{2}{*}{$\begin{array}{l}\text { Measured concentration, } \\
\mathrm{ng} / \mathrm{mL}\end{array}$} & \multirow[b]{2}{*}{$\mathrm{RSD}^{\mathrm{b}}$} & \multirow[b]{2}{*}{$\%$ Accuracy } & \multirow[b]{2}{*}{$\%$ RSEE $^{\mathrm{c}}$} & \multirow{2}{*}{$\begin{array}{l}\mathrm{LOD}^{\mathrm{d}} \\
\mathrm{ng} / \mathrm{mL}\end{array}$} \\
\hline & & $\mathrm{ng} / \mathrm{mL}$ & {$[\mathrm{nM}]$} & & & & & \\
\hline \multirow{4}{*}{ BHETM } & 11 & 13 & [80] & 14 & 6.8 & 111 & 4.4 & 10 \\
\hline & 12 & 130 & {$[800]$} & 119 & 7.4 & 92 & & \\
\hline & 12 & 325 & [2000] & 315 & 3.1 & 97 & & \\
\hline & 12 & 1300 & [8000] & 1319 & 2.6 & 101 & & \\
\hline \multirow[t]{4}{*}{ BHETE } & 12 & 15 & [80] & 15 & 5.0 & 100 & 2.8 & 8 \\
\hline & 12 & 150 & [800] & 153 & 4.2 & 102 & & \\
\hline & 12 & 375 & [2000] & 365 & 3.8 & 97 & & \\
\hline & 12 & 1500 & [8000] & 1506 & 1.5 & 101 & & \\
\hline \multirow[t]{4}{*}{ BHETPr } & 12 & 16 & [80] & 17 & 10.7 & 109 & 3.2 & 10 \\
\hline & 12 & 160 & [800] & 147 & 13 & 92 & & \\
\hline & 12 & 400 & [2000] & 392 & 2.9 & 98 & & \\
\hline & 12 & 1600 & [8000] & 1620 & 1.8 & 101 & & \\
\hline \multirow[t]{4}{*}{ BHETB } & 12 & 17 & [80] & 17 & 4.0 & 97 & 3.6 & 7 \\
\hline & 12 & 170 & [800] & 180 & 3.9 & 106 & & \\
\hline & 12 & 425 & [2000] & 410 & 3.1 & 96 & & \\
\hline & 12 & 1700 & [8000] & 1706 & 2.0 & 100 & & \\
\hline \multirow{4}{*}{ BHETPn } & 12 & 18 & [80] & 19 & 5 & 105 & 5.6 & 9 \\
\hline & 12 & 180 & [800] & 172 & 6.5 & 96 & & \\
\hline & 12 & 450 & [2000] & 445 & 9.4 & 99 & & \\
\hline & 12 & 1800 & [8000] & 1811 & 3.3 & 101 & & \\
\hline \multirow[t]{4}{*}{ BHETME } & 12 & 16 & [80] & 15 & 9.0 & 96 & 4.1 & 14 \\
\hline & 12 & 160 & [800] & 158 & 6.8 & 99 & & \\
\hline & 12 & 400 & [2000] & 426 & 4.6 & 106 & & \\
\hline & 12 & 1600 & [8000] & 1576 & 1.7 & 99 & & \\
\hline \multirow[t]{5}{*}{ BHETEE } & 11 & 1.8 & [8] & 1.9 & 7.5 & 108 & 8.1 & 4 \\
\hline & 12 & 18 & [80] & 16 & 7.9 & 91 & & \\
\hline & 12 & 180 & {$[800]$} & 180 & 6.9 & 100 & & \\
\hline & 12 & 450 & [2000] & 455 & 4.5 & 101 & & \\
\hline & 12 & 1800 & [8000] & 1796 & 5.5 & 100 & & \\
\hline
\end{tabular}

aSee Table 1 for precursor/product ion transitions (in bold and italics) measured.

'RSD: relative standard deviation.

'RSEE: relative standard error of the estimate.

dLOD: calculated limit of detection.

we examined the more favorable ionization technique of APCI in an effort to quantitate these compounds in the low $\mathrm{ng} / \mathrm{mL}$ range needed for biomonitoring purposes. In the course of examining the ionization characteristics of BHETAs and BHETAEs in positive and negative APCI, the superoxide anion was observed in negative ion APCI MS. We have shown that this characteristic superoxide adduct ion, $\left[\mathrm{M}+\mathrm{O}_{2}\right]^{-}$, is abundant and amenable to MS/MS, and that product ion scans of $\left[\mathrm{M}+\mathrm{O}_{2}\right]^{-}$exhibit a sufficient number of high-mass, high-intensity precursor/product ion transitions for analysis by MRM. We have demonstrated the stability and utility of the superoxide anion for specific identification and quantification of these compounds by establishing acceptable analytical figures of merit for three transitions. These characteristics support quantification and render APCI MS suitable for the development of a biomonitoring method that will exploit the advantages of MS/MS. The superoxide adduct ions are promising candidates for the quantification of these analytes from the low $\mathrm{ng} / \mathrm{mL}$ to $1800 \mathrm{ng} / \mathrm{mL}$ range and provide a quanti- tation ion and at least one confirmation ion with instrument detection limits between 2 and $16 \mathrm{ng} / \mathrm{mL}$, depending on the analyte. To our knowledge, we are the first to propose a quantitative mass spectrometry method predicated on the superoxide adduct anion and, thus, the first to suggest APCI MS as a viable alternative to ESI MS for the quantification of sesquiand oxy-mustard hydrolysis products.

Future work will address the development of an HPLC isotope dilution negative APCI MS/MS method based on superoxide adduct ions for the identification and quantification of BHETAs and BHETAEs in urine. The rearrangement of BHETME to BHETM should not present any difficulty provided the compounds are stable throughout the sample preparation procedure. A sample concentration step should prevent extraction losses from adversely affecting detection limits, and isotope-dilution will further compensate for extraction losses and the inherent variability in ionization efficiencies. Additionally, the use of appropriately distributed calibrants and labeled internal standards should reduce the influence of higher calibrants on 
(a)

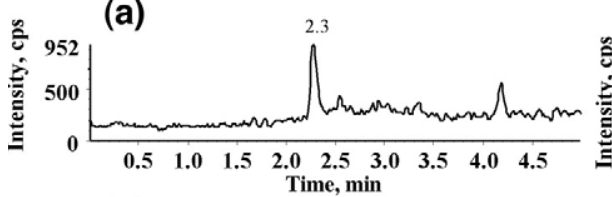

(b)

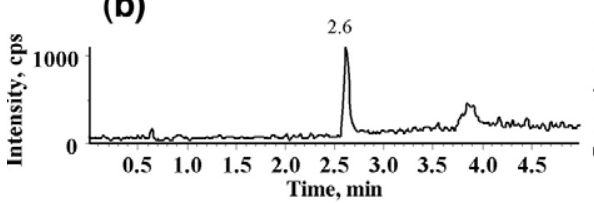

(c)

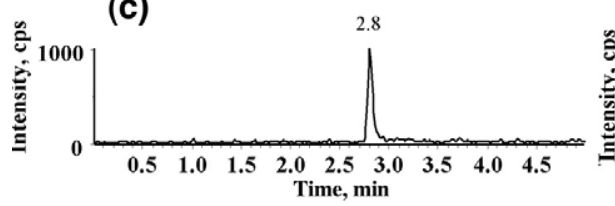

Time, $\min$

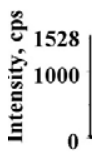

(d)

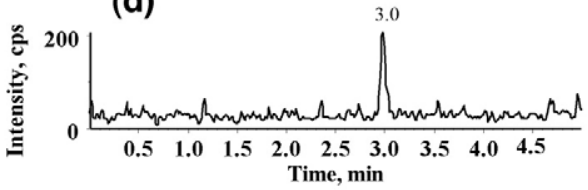

(e)

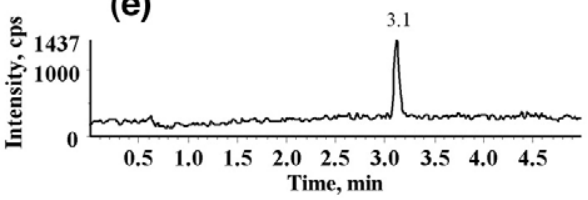

(f)

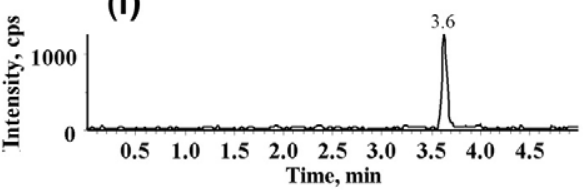

(g)

Time, $\min$

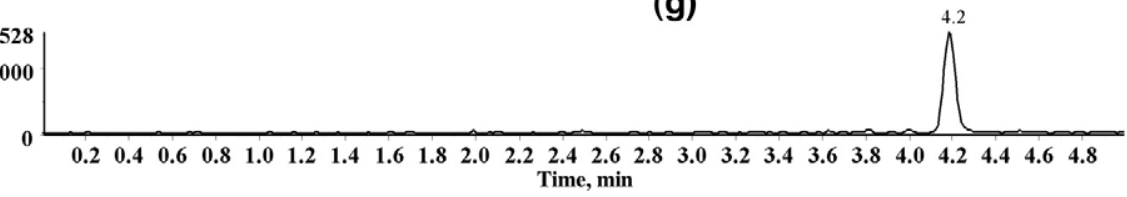

Figure 5. Extracted ion chromatograms showing the lowest intensity precursor/product ion pair at the lowest concentration level for each analyte in elution order: (a) bis(2-hydroxyethylthio)methane (BHETM), 200/167, 80 nM; (b) bis(2-hydroxyethylthio)ethane (BHETE), 214/181, $80 \mathrm{nM;} \mathrm{(c)} \mathrm{bis(2-}$ hydroxyethylthiomethyl)ether (BHETME), 230/153, $80 \mathrm{nM}$; (d) bis(2-hydroxyethylthioethyl)ether (BHETEE), 258/121, $8 \mathrm{nM}$; (e) bis(2-hydroxyethylthio)propane (BHETPr), 228/195, $80 \mathrm{nM}$; (f) bis(2-hydroxyethylthio)butane (BHETB), 242/165, $80 \mathrm{nM}$; (g) bis(2-hydroxyethylthio)pentane (BHETPn), 256/179, $80 \mathrm{nM}$.

the calibration curves and improve the reported figures of merit.

\section{References}

1. Report of the Mission Dispatched by the Security-General to Investigate Allegations of the Use of Chemical Weapons in the Conflict Between the Islamic Republic of Iran and Iraq; United Nations Report S/17911: New York, 1986.

2. Balali-Mood, M.; Hefazi, M. The Clinical Toxicology of Sulfur Mustard. Arch. Iranian Med. 2005, 8(3), 162-179.

3. Convention on the Prohibition of the Development, Production, Stockpiling, and Use of Chemical Weapons and on their Destruction; The Technical Secretariat of the Organization for the Prohibition of Chemical Weapons: The Hague, The Netherlands, 1992.

4. Bennett, G. M.; Whincop, E. M. Some Derivations of Monothioethlyene Glycol. J. Chem. Soc. Trans. 1921, 1860-1864.

5. Munro, N. B.; Talmage, S. S.; Griffin, G. D.; Waters, L. C.; Watson, A. P. King, J. F.; Hauschild, V. The Sources, Fate, and Toxicity of Chemical Warfare Agent Degradation Products. Environ. Health Perspect. 1999, 107(12), 933-974.

6. D'Agostino, P. A.; Provost, L. R.; Hancock, J. R. Analysis of Mustard Hydrolysis Products by Packed Capillary Liquid ChromatographyElectrospray Mass Spectrometry. J. Chromatogr. A 1998, 808, 177-184.

7. D'Agostino, P. A.; Provost, L. R. Capillary Column Isobutane Chemical Ionization Mass Spectrometry of Mustard and Related Compounds. Biomed. Environ. Mass Spectrom. 1988, 15(10), 553-564.

8. Gasson, E. J.; McCombie, H.; Williams, A. H.; Woodward, F. N. New Organic Sulfur Vesicants. Part IV. 1:2-Di-(2-Chloroethylthio)Ethane and Its Analogues. J. Chem. Soc. 1948, 44-46.

9. Robinson, J. P. Chemical Warfare. Sci. J. 1967, 4, 33-40.

10. Watson, A. P.; Griffin, G. D. Toxicity of Vesicant Agents Scheduled for Destruction by the Chemical Stockpile Disposal Program. Environ. Health Perspect. 1992, 98, 259-280.

11. Roberts, J. J.; Warwick, G. P. Studies of the Mode of Action of Alkylating Agents. VI. The Metabolism of Bis-2-chloroethylsulphide (Mustard Gas) and Related Compounds. Biochem. Pharmacol. 1963, 12, 1329-1334.

12. Davison, C.; Rozman, R. S.; Smith, P. K. Metabolism of Bis- $\beta$-chloroethyl Sulfide (Sulfur Mustard Gas). Biochem. Pharmacol. 1961, 7(1), 65-74.

13. Black, R. M.; Brewster, K.; Clarke, R. J.; Hambrook, J. L.; Harrison, J. M.; Howells, D. J. Biological Fate of Sulphur Mustard, 1,1'-Thiobis(2chloroethane): Isolation and Identification of Urinary Metabolites Fol- lowing Intraperitoneal Administration to Rat. Xenobiotica 1992, 22(4), 405-418.

14. Fidder, A.; Noort, D.; de Jong, L. P. A.; Benschop, H. P.; Hulst, A. G. N7-(2-Hydroxyethylthioethyl)-Guanine: A Novel Urinary Metabolite Following Exposure to Sulphur Mustard. Arch. Toxicol. 1996, 70(12), $854-855$.

15. Sandelowsky, I.; Simon, G. A.; Bel, P.; Barak, R.; Vincze, A. N1-(2Hydroxyethylthioethyl)-4-Methyl imidazole (4-met-1-imid-Thiodiglycol) in Plasma and Urine: A Novel Metabolite Following Dermal Exposure to Sulphur Mustard. Arch. Toxicol. 1992, 66(4), 296-297.

16. Bartelt-Hunt, S. L.; Barlaz, M. A.; Knappe, D. R. U.; Kjeldsen, P. Fate of Chemical Warfare Agents and Toxic Industrial Chemicals in Landfill. Environ. Sci. Technol. 2006, 40(13), 4219-4225.

17. Timperley, C. M.; Black, R. M.; Bird, M.; Holden, I.; Mundy, J. L.; Read, R. W. Hydrolysis and Oxidation Products of the Chemical Warfare Agents 1,2-Bis[(2-Chloroethyl)thio]Ethane Q and 2,2'-Bis(2-Chloroethylthio)Diethyl Ether T. Phosphorus, Sulfur, Silicon 2003, 178(9), 20272046.

18. D'Agostino, P. A.; Provost, L. R. Capillary Column Electron Impact and Ammonia Chemical Ionization Gas Chromatographic-Mass Spectrometric and Gas Chromatographic-Tandem Mass Spectrometric Analysis of Mustard Hydrolysis Products. J. Chromatogr. A 1993, 645(2), 283-292.

19. St. Quintin, T. D.; Leslie, D. R.; Collins, J. G. Hydrolysis of Sesquimustards. Aust. J. Chem. 2003, 56(4), 309-313.

20. D'Agostino, P. A.; Provost, L. R. Gas Chromatographic Retention Indices of Sulfur Vesicants and Related Compounds. J. Chromatogr. 1988, 436(3), 399-411.

21. D'Agostino, P. A.; Provost, L. R.; Hansen, A. S.; Luoma, G. A. Identification of Mustard Related Compounds in Aqueous Samples by Gas Chromatography/Mass Spectrometry. Biomed. Environ. Mass Spectrom. 1989, 18, 484-491.

22. Black, R. M.; Read, R. W. Improved Methodology for the Detection and Quantitation of Urinary Metabolites of Sulphur Mustard Using Gas Chromatography-Tandem Mass Spectrometry. J. Chromatogr. B 1995, 665(1), 97-105.

23. Black, R. M.; Read, R. W. Detection of Trace Levels of Thiodiglycol in Blood, Plasma, and Urine Using Gas Chromatography-ElectronCapture Negative-Ion Chemical Ionization Mass Spectrometry. J. Chromatgr. 1988, 449(1), 261-270.

24. Munavalli, S.; Jakubowski, E. M.; Durst, H. D. Liquid Chromatography Thermospray Mass Spectrometry of Mustard and Its Metabolites. J. Mass Spectrom. 1995, 30(12), 1716-1722.

25. Borrett, V. T.; Mathews, R. J.; Colton, R.; Traeger, J. C. Verification of the United Nations Chemical Weapons Convention: the Application of 
Electrospray Mass Spectrometry. Rapid Commun. Mass Spectrom. 1996, 10, 114-118.

26. D'Agostino, P. A.; Hancock, J. R.; Chenier, C. L. Packed Capillary Liquid Chromatography-Electrospray Ionization (Tandem) Mass Spectrometry of Mustard Hydrolysis Products in Soil. J. Chromatogr. A 2004, 1058(1/ 2), 97-105.

27. Smith, J. R.; Shih, M. L. Analysis of the Degradation Compounds of Chemical Warfare Agents using Liquid Chromatography/Mass Spectrometry. J. Appl. Toxicol. 2001, 21, S27-S34.

28. D'Agostino, P. A.; Hancock, J. R.; Chenier, C. L. Mass Spectrometric Analysis of Chemical Warfare Agents and their Degradation Products in Soil and Synthetic Samples. Eur. J Mass Spectrom. 2003, 9(6), 609-618.

29. Tak, V.; Kanaujia, P. K.; Pardasani, D.; Gupta, A. K.; Palit, M.; Srivastava, R. K.; Dubey, D. K. Electrospray Ionization Tandem Mass Spectral Analysis of Oxidation Products of Precursors of Sulfur Mustards. Rapid Commun. Mass Spectrom. 2006, 20(16), 2387-2394.

30. Black, R.; Read, R. W. Application of Liquid ChromatographyAtmospheric Pressure Chemical Ionization Mass Spectrometry and
Tandem Mass Spectrometry, to the Analysis and Identification of Degradation Products of Chemical Warfare Agents. J. Chromatogr. A 1997, 759, 79-92.

31. Read, R. W.; Black, R. M. Rapid Screening Procedures for the Hydrolysis Products of Chemical Warfare Agents using Positive and Negative Ion Liquid Chromatography-Mass Spectrometry with Atmospheric Pressure Chemical Ionization. J. Chromatogr. A 1999, 862, 169-177.

32. Willoughby, R.; Sheehan, E.; Mitrovich, S. A Global View of LC/MS: How to Solve your Most Challenging Analytical Problems; Global View Publishing: Pittsburgh, 2002, p 65

33. Horning, E. C.; Horning, M. G.; Carroll, D. I.; Dzidic, I.; Stillwell, R. N. New Picogram Detection System Based on a Mass Spectrometer with an External Ionization Source at Atmospheric Pressure. Anal. Chem. 1973, 45(6), 936-943.
34. Grimalt, S.; Pozo, O. J.; Marin, J. M.; Sancho, J. V.; Hernandez, F. Evaluation of Different Quantitative Approaches for the Determination of Non-easily Ionizable Molecules by Different Atmospheric Pressure Interfaces Used in Liquid Chromatography Tandem Mass Spectrometry: Abamectin as Case of Study. J. Am. Soc. Mass Spectrom. 2005, 16(10), 1619-1630.

35. Diehl, G.; Karst, U. On-line Electrochemistry-MS and Related Techniques. Anal. Bioanal. Chem. 2002, 373(6), 390-398.

36. Hunt, D. F.; McEwen, C. N.; Harvey, T. M. Positive and Negative Chemical Ionization Mass spectrometry Using a Townsend Discharge Ion Source. Anal. Chem. 1975, 47(11), 1730-1734.

37. Chapman, J. R. Practical Organic Mass Spectrometry; John Wiley and Sons, Inc.: New York, 1993, p 115.

38. Budzikiewicz, H. Negative Chemical Ionization (NCI) of OrganicCompounds. Mass Spectrom. Rev. 1986, 5(4), 345-380.

39. Moruzzi, J. L.; Phelps, A. V. Survey of Negative-Ion-Molecule Reactions in $\mathrm{O}_{2}, \mathrm{CO}_{2}, \mathrm{H}_{2} \mathrm{O}, \mathrm{CO}$, and Mixtures of These Gases at High Pressures. J. Chem. Phys. 1966, 45(12), 4617-4627.

40. Horning, E. C.; Carroll, D. I.; Dzidic, I.; Haegele, K. D.; Horning, M. G.; Stillwell, R. N. Liquid Chromatograph-Mass Spectrometer-Computer Analytical Systems. A Continuous-Flow System Based on Atmospheric Pressure Ionization Mass Spectrometry. J. Chromatogr. 1974, 99, 13-21.

41. Dzidic, I.; Carroll, D. I.; Stillwell, R. N.; Horning, E. C. Atmospheric Pressure Ionization (API) Mass Spectrometry: Formation of Phenoxide Ions from Chlorinated Aromatic Compounds. Anal. Chem. 1975, 47(8), 1308-1312.

42. Dzidic, I.; Carroll, D. I.; Stillwell, R. N.; Horning, E. C. Gas Phase Reactions. Ionization by Proton Transfer to Superoxide Anions. J. Am. Chem. Soc. 1974, 96(16), 5258-5259.

43. Taylor, J. K. Quality Assurance of Chemical Measurements; CRC Press, Inc.: Boca Raton, FL, 1987; pp 79-83 